\title{
Bee Venom Exerts Neuroprotective Effects on Neuronal Cells and Astrocytes under Hypoxic Conditions Through MAPK Signaling Pathways
}

Eun Joo Lee, M.D., Bong Jae Kim, M.D., Ji Eun Jeong, M.D., Hai Lee Chung, M.D., Eun Kyoung Yang, M.D.*, and Woo Taek Kim, M.D.

Department of Pediatrics, Catholic University of Daegu School of Medicine, Daegu, Korea

Department of Physiology*, Kyungpook National University School of Medicine, Daegu, Korea

\section{ABSTRACT}

Purpose: Hypoxic-ischemic brain injuries influence the mechanisms of signal transduction, including mitogen-activated protein kinase (MAPK) that regulates gene expression through transcription factor activity. Several attempts have been made to use bee venom (BV) to treat neurological diseases. However, limited data are available for brain injuries such as neonatal hypoxic-ischemic encephalopathy (HIE) and neurodegenerative disorders. The purpose of this study was to investigate the neuroprotective effects of BV by determining the expression of activated MAPK pathways. Methods: We examined activation and cell viability in hypoxia $\left(1 \% \mathrm{O}_{2}, 5 \% \mathrm{CO}_{2}, 94 \%\right.$ $\mathrm{N}_{2}$ ) in low glucose-treated (H+low $\mathrm{G}$ ) neuronal cells and astrocytes in the presence and absence of BV. After they were subjected to hypoxic conditions and treated with low glucose, the cells were maintained for $0,6,15$, and $24 \mathrm{~h}$ under normoxic conditions.

Results: Extracellular-signal-regulated kinases 1/2 (ERK1/2), p38 MAPK, and stressactivated protein kinases (SAPK)/Jun amino-terminal kinases (JNK) were activated in H+low G conditions. Particularly, phosphorylation of ERK1/2 was maximized $6 \mathrm{~h}$ after exposure to $\mathrm{H}+$ low $\mathrm{G}$ condition. BV specifically inhibited the phosphorylation of ERK1/2. However, BV had no effect on p38 MAPK or SAPK/JNK. In addition, BV improved neuronal cell and astrocytes viability following exposure to $\mathrm{H}+$ low $\mathrm{G}$.

Conclusion: ERK inactivation is known to mediate protective effects in hypoxic brain injury. Taken together, these results suggest that treatment with BV may be helpful in reducing hypoxic injury in neonatal HIE through the ERK signaling pathway.

Key Words: Bee venom, Hypoxia, MAPK pathway, Astrocyte, Neuronal cell, Neuroprotective
Received: 9 September 2015

Revised: 25 November 2015

Accepted: 25 November 2015

Correspondence to:

Woo Taek Kim, M.D., Ph.D.

Division of Neonatology,

Department of Pediatrics, Catholic

University of Daegu School of

Medicine, 33, Duryugongwon-ro 17 -

gil, Nam-gu, Daegu 42472, Korea

Tel: +82-53-650-4250

Fax: +82-53-622-4240

E-mail: wootykim@hanmail.net

Copyright(c)

By Korean Society of Neonatology.

All right reserved.

This is an Open-Access article distributed under the terms of the Creative Commons Attribution Non-Commercial License (http://creativecommons.org/licenses/ by-nc/4.0), which permits unrestricted non-commercial use, distribution, and reproduction in any medium, provided the original work is properly cited. 


\section{INTRODUCTION}

Bee venom (BV) has been used for medical purposes around the world, particularly in oriental countries. Recently, the Food and Drug Administration (FDA) approved the use of BV for allergy desensitization ${ }^{1)}$. BV has many biologic activities including anti-inflammatory, anti-neurotoxic, anti-bacterial, antiallergic, and anti-hypertensive effects and regulatory functions in the autonomic nervouse system ${ }^{2-4}$. BV has been used to treat rheumatioid arthritis, Parkinson's disease, multiple sclerosis, neuro-muscular pain syndrome, skin disease, and immune disease $^{5,6)}$.

BV contains various peptides, enzymes, and non-peptide components. BV peptides include melittin, apamin, mast cell degranulation peptide and adolapin.

The non-peptide components of BV consist of histamine, dopamine, noradrenaline, carbohydrates and some lipids. BV enzymes include phospholipase $\mathrm{A}_{2}$ ( $\mathrm{PLA}_{2}$ ), hyaluronidase, acid phosphomonoesterase, $\alpha$-d-glucosidase, and lypophospholipase $^{7)}$.

Hypoxic-ischemic brain injury is a pathological insult that resulting in energy failure caused by low arterial oxygen tension and inadequate blood flow ${ }^{8,9)}$. The cerebral neuronal response to hypoxia results in a massive release of glutamate followed by calcium influx, inflammatory cytokine release, and reactive oxygen species (ROS) formation ${ }^{10,11)}$. These conditions cause a critical shortage of energy (energy crisis). There is growing evidence that the mechanisms underlying the neuronal damage caused by hypoxia involve the activation of multiple intracellular signal transduction pathways ${ }^{12,13)}$. These signal transduction pathways modulate multiple kinases including protein kinase $\mathrm{C}$ and mitogen activated protein kinase (MAPK) ${ }^{8}$. The MAPK family is mainly composed of key regulatory proteins that control inflammation and physiological processes. These protein are regulated by phosphorylation cascades ${ }^{14,15)}$, and phosphorylation plays a crucial role in their regulatory function ${ }^{16)}$.

In mammals, there are at least three distinct groups of MAPKs, including extracellular-signal-regulated kinases 1/2 (ERK1/2), stress-activated protein kinases (SAPK)/Jun amino-terminal kinases (JNK) and p38 MAPK. MAPKs transduce a wide range of extracellular stimuli into various cellular responses by producing changes in the transcription of key genes. They also targets protein expression and play an important role in re- gulating neuronal death after hypoxia ${ }^{17,18)}$.

ERKs are widely expressed in nervous tissue and are associated with cell survival ${ }^{19)}$. They are activated by growth factors, intracellular calcium increases, glutamate receptor stimulation and mitogenic stimuli, and are involved in cell proliferation, division, development and differentiation ${ }^{20)}$. On the other hand, SAPK/JNK and p38 MAPK are activated in response to various stresses such as hyperosmosis, oxidative stress, ultraviolet radiation, inflammatory cytokines, DNA damage and heat shock proteins. Through modulation of transcriptional factors expression, they are involved in apoptosis, inflammation, cell cycle arrest, and cell differentiation ${ }^{19,21)}$.

BV exerts anti-inflammatory effects by inhibiting nuclear factor kappa-B (NF- $\mathrm{kB}$ ) activation and modulating the expression of various inflammatory cytokines such as tumor necrosis factor alpha ${ }^{2,3)}$. BV is known to downregulate inducible nitric oxide synthase and cyclooxygenase-2, possibly through NF- $\mathrm{\kappa B}$ and MAPK activation in neuronal and glial cells ${ }^{3,22}$. Additionally, melittin, a major component of BV, has anti-inflammatory effects by decreasing the expression of inflammatory cytokines through the regulation of NF- $\mathrm{KB}$ and MAPK signaling pathways ${ }^{23)}$. Finally, prion protein-mediated activation of p38 MAPK and cleaved caspases and the inactivation of Akt are blocked by BV $\mathrm{PLA}_{2}{ }^{24)}$.

Limited data are available for brain injuries such as neonatal hypoxic-ischemic encephalopathy, neurodegenerative disorders and excitotoxicity. Furthermore, it is not clearly understood whether BV can function as a neuroprotective agent, and whether it has effects on members of MAPK involved in the neuroprotection of hypoxia-induced injuries in neuronal model systems. Therefore, the aim of the present study was to investigate whether BV could reduce cell injury following exposure to hypoxic and low-glucose condition (H+low G). This study also evaluated whether MAPK pathways, including ERK, p38 MAPK and SAPK/JNK, are associated with the mechanisms of the neuroprotective effects of BV.

\section{MATERIALS AND METHODS}

\section{Materials (Chemicals and Reagents)}

BV was obtained from the National Institute of Agricultural Science and Technology, Suwon, Korea. BV was collected with a BV collecting device (Chung-Jin Biotech Ltd., Ansan, Korea) 
under sterile laboratory conditions. Poly- $D$-lysine was purchased from Sigma (St. Louis, MO, USA). Secondary goat antirabbit IgG-HRP was obtained from Santa Cruz Biotechnology (Santa Cruz, CA, USA). Phospho-p44/42MAPK (ERK1/2), p44/ 42MAPK (ERK1/2), phospho-p38 MAPK, p38 MAPK, phosphoSAPK/JNK, and SAPK/JNK antibodies were purchased from Cell Signaling Technology (Danvers, MA, USA). 3-(4,5-dimethylthiazol-2-yl)-2,5-diphenyl-tetrazoliumbromide (MTT) was from Duchefa (Haarlem, The Netherlands). Hanks' balanced salt solution (HBSS), Neurobasal media, B27 supplement, glutamax I, and HEPES were obtained from GibcoBRL (Invitrogen, Grand Island, NY, USA). Dulbecco's Modified Eagle's Medium DMEM (high glucose-4,500 mg/L, low glucose-1,000 mg/L), fetal bovine serum (FBS), penicillin-streptomycin, and trypsinEDTA were obtained from Hyclone Laboratories (Logan, UT, USA). Enhanced chemiluminoscence kit and a western blotting detection system were purchased from Amersham Biosciences (Piscataway, NJ, USA).

\section{Cortical Neuronal Cell and Astrocyte Cultures}

This study was performed in accordance with the approved animal use guidelines of the Catholic University of Daegu. Culture of cortical neuronal cells from rat embryos followed the Brewer method $^{25)}$. To obtain primary cultured cortical neurons, the cortex was dissected from an embryonic 14-day-old (E14, both sexes) Sprague Dawley rat brain. The blood vessels and meninges were removed under a microscope, and the cortices were then dissected in $37^{\circ} \mathrm{C}$ HBSS containing $1 \mathrm{mM}$ sodium pyruvate and $10 \mathrm{mM}$ HEPES ( $\mathrm{pH}$ 7.4). The dissected brain cortical tissues were placed in $2 \mathrm{~mL}$ trypsin and incubated in $37^{\circ} \mathrm{C}$ water bath for $1 \mathrm{~min}$ to dissociate the cells. After washing five times with $10 \mathrm{~mL}$ HBSS, the cells were rinsed in $1 \mathrm{~mL} \mathrm{HBSS}$, and gently dissociated by several passages through a small-bore Pasteur pipette. The cell suspension was centrifuged at 1,000 $\mathrm{rpm}$ at $25^{\circ} \mathrm{C}$ for $5 \mathrm{~min}$. Cell pellets were washed with HBSS (without phenol red). The cells were suspended in Neurobasal media supplemented with $2 \%$ B27 and $0.5 \mathrm{mM}$ glutamax I. Cells were seeded at a density of $2 \times 10^{6}$ cells $/ \mathrm{mm}^{2}$ onto culture dish precoated with $50 \mu \mathrm{g} / \mathrm{mL}$ poly- $D$-lysine. Cultures were maintained in Neurobasal media at $37^{\circ} \mathrm{C}$ in $95 \%$ humidified air with $5 \% \mathrm{CO}_{2}$.

Cortical astrocytes used for the primary cultures were prepared from the cerebral cortices of 1-day-old Sprague Dawley rats (both sexes) as previously described ${ }^{26)}$. In summary, the brains were carefully collected and transferred into prechilled HBSS under sterile condition. Meninges were carefully removed under a microscope. The cortex was chopped into pieces and resuspended in $3 \mathrm{~mL} 0.25 \%$ trypsin solution. After incubation at $37^{\circ} \mathrm{C}$ for $20 \mathrm{~min}$, FBS was added to stop the action of trypsin. Following centrifugation at 1,000 rpm for $2 \mathrm{~min}$, the cell pellet was dissociated in to single cells by pipetting several times, then passed through 80 mesh screens. After washing the suspension in phosphate buffered saline (PBS, pH 7.4) and centrifugation at 1,000 rpm for $5 \mathrm{~min}$, dissociated single cells were incubated with DMEM (high glucose) supplemented with 10\% FBS, 25 mm HEPES, 2 mm l-glutamine, $100 \mathrm{U} / \mathrm{mL}$ penicillin, and $100 \mathrm{lg} / \mathrm{mL}$ streptomycin at a density of $3 \times 10^{5}$ cells/ $\mathrm{mL}$. Cells were plated onto culture dishes and placed in conditions of $37^{\circ} \mathrm{C}$ and $95 \%$ air with $5 \% \mathrm{CO}_{2}$.

For normoxia (N group), cells were placed in DMEM with high glucose $(4,500 \mathrm{mg} / \mathrm{L})$ and then incubated under normoxia conditions. For $\mathrm{H}+$ low $\mathrm{G}$ condition, cells were gently washed with PBS. DMEM containing low glucose $(1,000 \mathrm{mg} / \mathrm{L})$ was added to the culture dish. Neuronal cells were pretreated with a $0.4 \mu \mathrm{g} / \mathrm{mL}$ concentrations of BV for $1 \mathrm{~h}$. Astrocytes were pretreated with a $2.5 \mu \mathrm{g} / \mathrm{mL}$ concentrations of BV for $1 \mathrm{~h}$. Cells were placed in a hypoxia chamber (Billups-Rothenberg, Del Mar, CA, USA) and flushed with $1 \% \mathrm{O}_{2}$ (premixed $1 \% \mathrm{O}_{2}, 5 \%$ $\mathrm{CO}_{2}, 94 \% \mathrm{~N}_{2}$ ) for $5 \mathrm{~min}$ at a rate of $20 \mathrm{~L} / \mathrm{min}$. The chamber was sealed and placed at $37^{\circ} \mathrm{C}$ for $9 \mathrm{~h}$ (neuronal cells) or $18 \mathrm{~h}$ (astrocytes). Cells were returned to culture conditions and assessed $0,6,15$, and $24 \mathrm{~h}$ following exposure to $\mathrm{H}+$ low $\mathrm{G}$ condition. All experiments were performed at least four times.

\section{3-(4,5-dimethylthiazol-2-yl)-2,5-diphenyl-tetrazolium bromide (MTT) Assay}

An MTT assay was used to evaluate cell viability and cell growth. Cells were plated into 96-well cell culture plates. Cells were incubated in the presence of $0.5 \mathrm{mg} / \mathrm{mL}$ MTT. After 3-4 hours of incubation at $37^{\circ} \mathrm{C}$ in the dark, the medium was removed and the formazan dye was extracted using $100 \mu \mathrm{L}$ of the lysing buffer (1:1 dimethyl sulfoxide:95\% ethanol). Absorbance of the samples was determined at $540 \mathrm{~nm}$ using a microtiter plate enzyme-linked immunosorbent assay reader. The amount of formazan produced was proportional to the number of live and metabolically active cells. 


\section{Protein Extraction for Neuronal Cells and Astrocytes}

Growth medium from the cells was removed by aspiration. Cells were washed with PBS to remove residual medium. Cells were extracted with radioimmunoprecipitation assay lysis buffer (Rockland, Gilbertsville, PA, USA). After incubation for 5 min on ice, total cell extracts were centrifuged at 12,000 rpm at $4^{\circ} \mathrm{C}$ for $10 \mathrm{~min}$. Protein-containing supernatants were collected. Proteins were quantified using a BCA Protein Assay Kit (Thermo Scientific, Rockford, IL, USA) by taking spectrophotometric readings at $540 \mathrm{~nm}$. Concentrations were estimated against a standard curve of bovine serum albumin (BSA).

\section{Sodium Dodecyl Sulfate-Polyacrylamide Gel Electro- phoresis (SDS-PAGE) and Western Blot Analysis}

A total of $30 \mu \mathrm{g}$ of protein from each sample was loaded for $12 \%$ SDS-PAGE after denaturing in $5 \mathrm{x}$ SDS gel-loading buffer (60 mM Tris-HCl pH 6.8, 25\% glycerol, 2\% SDS, 14.4 mM 2mercaptoehanol and $0.1 \%$ bromophenol blue) in boiling water for $10 \mathrm{~min}$. At the end of electrophoresis, proteins were electrotransferred onto a polyvinylidene difluoride membrane (Millipore, Bedford, MA, USA) at a constant voltage of $10 \mathrm{~V}$ for 27 $\mathrm{min}$. After transfer, the membrane was washed for $10 \mathrm{~min}$ in $1 \mathrm{x}$ Tris-buffered saline (TBS) with $0.1 \%$ Tween-20 (TBST, pH 7.4) and preincubated with a blocking buffer (5\% BSA in TBST) at room temperature (RT) for $1 \mathrm{~h}$. The blots were then incubated with phospho-p44/42MAPK (p-ERK1/2), p44/42MAPK (ERK1/2), phospho-p38 MAPK (p-p38 MAPK), p38 MAPK, phospho-SAPK/JNK (p-SAPK/JNK), or SAPK/JNK primary antibodies at 1:1,000 dilutions in blocking buffer at $4^{\circ} \mathrm{C}$ overnight. Next, the membrane was incubated with secondary antirabbit antibody conjugated with horseradish peroxidase a
1:2,000 dilution at RT for $1 \mathrm{~h}$. Finally, the membrane was washed and visualized by using the ECL plus kit. The intensities of the western blot bands were measured using a densitometer (Multi Gauge Software, Fuji Photofilm, Tokyo, Japan).

\section{Statistics Analysis}

Data were analyzed using the SPSS version 22 (SPSS Inc., Chicago, IL, USA) statistical analysis package. Examined data were assessed using the $t$-test, and ANOVA. In each test, the data were expressed as the mean \pm standard deviation using Excel 2007. A $P$-value lower than 0.05 was as considered statistically significant.

\section{RESULTS}

\section{Optimal Concentration of BV in Neuronal Cells and Astro- cytes}

To find the optimum concentration of $\mathrm{BV}$, cell viabilities were measured after treatment with different concentrations of $\mathrm{BV}$ for $24 \mathrm{~h}$ (Figure 1). While concentrations of $0.2 \mathrm{or} 0.4 \mu \mathrm{g} / \mathrm{mL} \mathrm{BV} \mathrm{did}$ not show cellular toxicity, neuronal cells treated with a 0.8 to 3 $\mu \mathrm{g} / \mathrm{mL}$ concentration of BV showed a statistically significant decrease in viability $(P<0.01, \mathrm{n}=4$, Figure $1 \mathrm{~A} ; 0.0 \mu \mathrm{g} / \mathrm{mL}, 100 \pm 1 \%$; $0.2 \mu \mathrm{g} / \mathrm{mL}, 104 \pm 1 \% ; 0.4 \mu \mathrm{g} / \mathrm{mL}, 107 \pm 2 \% ; 0.6 \mu \mathrm{g} / \mathrm{mL}, 98 \pm 5 \% ; 0.8$ $\mu \mathrm{g} / \mathrm{mL}, 86 \pm 4 \% ; 1.0 \mu \mathrm{g} / \mathrm{mL}, 83 \pm 3 \% ; 3.0 \mu \mathrm{g} / \mathrm{mL}, 72 \pm 5 \%)$. At concentrations above $5 \mu \mathrm{g} / \mathrm{mL}$, BV significantly caused a decrease in astrocyte viability $(P<0.01, \mathrm{n}=4$, Figure $1 \mathrm{~B} ; 0.0 \mu \mathrm{g} / \mathrm{mL}, 100 \pm 3 \%$; $0.8 \mu \mathrm{g} / \mathrm{mL}, 104 \pm 4 \% ; 1.5 \mu \mathrm{g} / \mathrm{mL}, 107 \pm 4 \% ; 2.5 \mu \mathrm{g} / \mathrm{mL}, 112 \pm 2 \% ; 5.0$ $\mu \mathrm{g} / \mathrm{mL}, 92 \pm 4 \% ; 7.0 \mu \mathrm{g} / \mathrm{mL}, 77 \pm 3 \% ; 9.0 \mu \mathrm{g} / \mathrm{mL}, 57 \pm 5 \%)$. These results indicated that the optimum concentrations of $\mathrm{BV}$ for
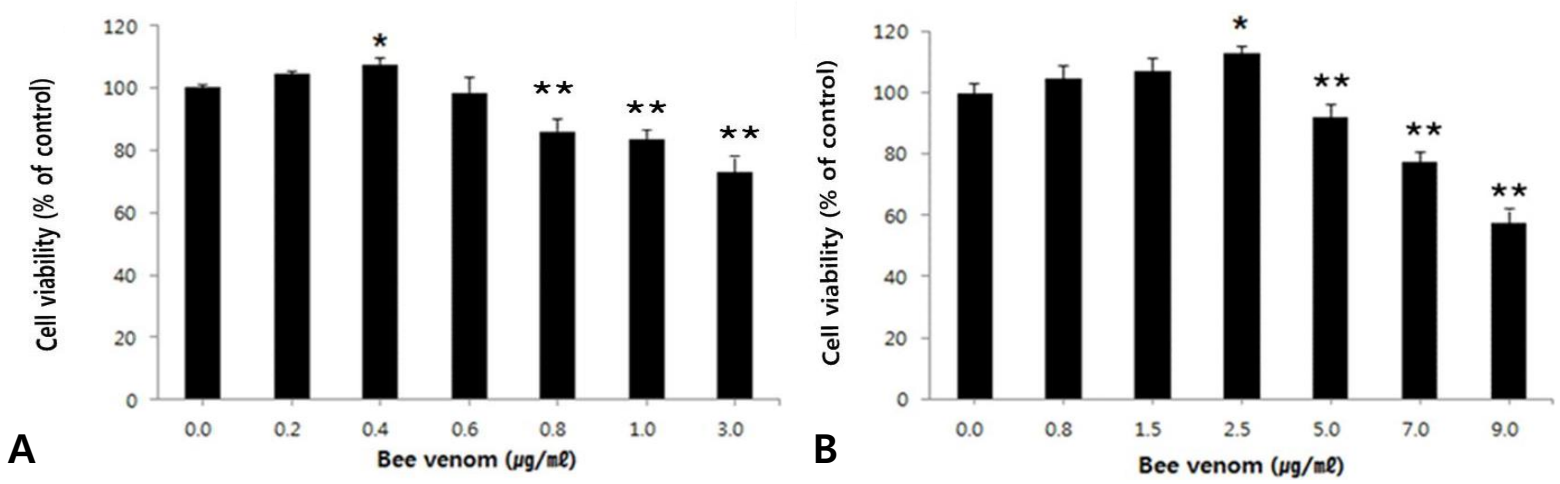

Figure 1. Cell viabilities as determined by the 3-(4,5-dimethylthiazol-2-yl)-2,5-diphenyl-tetrazolium bromide (MTT) assay. Cells were treated with the indicated concentrations of bee venom for $24 \mathrm{~h}$. (A) Neuronal cells (B) Astrocytes $\left({ }^{*} P<\right.$ $0.05,{ }^{* *} P<0.01$ compared to the control group $\left.[0.0 \mu \mathrm{g} / \mathrm{mL}]\right)$. 
relative cell viabilities of neuronal cells and astrocytes were 0.4 and $2.5 \mu \mathrm{g} / \mathrm{mL}$, respectively. Thus, all experiments in the present study were done using these optimum concentrations of BV.

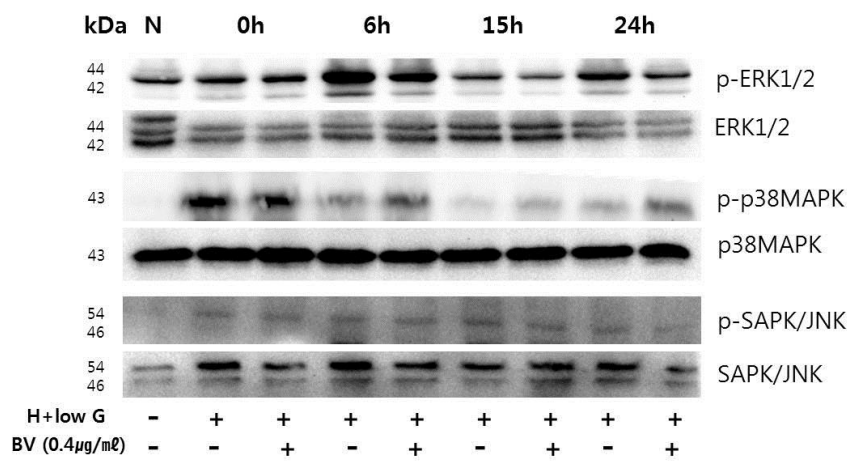

Figure 2-1. Western blot analysis of MAPK signaling pathways following exposure to $\mathrm{H}+$ low $\mathrm{G}$ conditions in both the $\mathrm{H}+$ low $\mathrm{G}$ group and the $\mathrm{BV}+\mathrm{H}+$ low $\mathrm{G}$ group in neuronal cells. Neuronal cells were pretreated with $0.4 \mu \mathrm{g} / \mathrm{mL}$ of bee venom (BV) for $1 \mathrm{~h}$ and then exposed to by $\mathrm{H}+$ low $\mathrm{G}$ conditions for $9 \mathrm{~h}$. Nuclear extracts were subjected to a western blot, using antibodies against ERK1/ 2, p38 MAPK, SAPK/JNK, p-ERK1/2, p-p38 MAPK, and p-SAPK/ JNK. p-ERK1/2, p-p38 MAPK, and p-SAPK/JNK denote antibodies against the phosphorylated form of each protein. $\mathrm{H}+$ low $\mathrm{G}$, and $\mathrm{BV}+\mathrm{H}+$ low $\mathrm{G}$ denote conditions of hypoxia with low glucose alone and BV-pretreated hypoxia with low glucose, respectively. MAPK represents mitogen-activated protein kinase. $\mathrm{N}$ represents normoxia. The elapsed time after exposure to $\mathrm{H}+$ low $\mathrm{G}$ conditions is represented by $0 \mathrm{~h}, 6 \mathrm{~h}, 15 \mathrm{~h}$, and $24 \mathrm{~h}$. ERK1/2, extracellular-signalregulated kinases $1 / 2$; SAPK/JNK, stress-activated protein kinases (SAPK)/Jun amino-terminal kinases (JNK).

\section{Effect of BV Pretreatment on Activation of MAPKs in Neu- ronal Cells Following Exposure to $\mathrm{H}+$ low $\mathrm{G}$ Condition}

The time course of non-phosphorylated ERK1/2, p38 MAPK, SAPK/JNK, p-ERK1/2, p-p38 MAPK, and p-SAPK/JNK activity was measured in neuronal cells $0,6,15$, and $24 \mathrm{~h}$ following exposure $\mathrm{H}+$ low $\mathrm{G}$ conditions with or without be BV pretreatment (Figure 2-1, Figure 2-2).

In neuronal cells, phosphorylation of ERK was increased about 1.5- to 3.5-fold in the $\mathrm{H}+$ low $\mathrm{G}$ group compared to the $\mathrm{N}$ group. It attained a peak phosphorylation level at $6 \mathrm{~h}$ but dropped to the lowest level at $15 \mathrm{~h}$ following exposure to $\mathrm{H}+\mathrm{low}$ G condition ( $n=6$, Figure 2-2A; N, 1.00 \pm 0.03 ; 0 h H+low G, 1.49 $\pm 0.08 ; 6$ h H+low G, 3.52 $\pm 0.12 ; 15$ h H+low G, 1.07 $\pm 0.13 ; 24$ h H+low G, 1.55 \pm 0.15$)$. Phosphorylations of p38 MAPK ( $n=6$, Figure 2-2B; N, 1.00 $\pm 0.24 ; 0$ h H+low G, 4.64 $\pm 0.50 ; 6$ h H+low G,

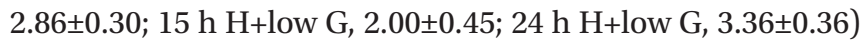

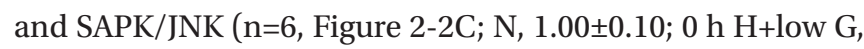

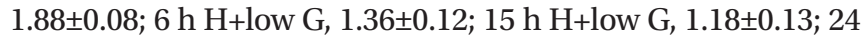
h H+low G, 0.99 \pm 0.15 ) were increased about 4.6- and 2-fold after hypoxic insult in the $\mathrm{H}+$ low $\mathrm{G}$ group compared to the $\mathrm{N}$ group, respectively (Figure 2-2B and Figure 2-2C). Thereafter, the phosphorylation of SAPK/JNK decreased over time (Figure 2-2C). The phosphorylation of p38 MAPK also tended to decrease over time. It showed the lowest level of phosphorylation $15 \mathrm{~h}$ following exposure to $\mathrm{H}+\mathrm{low} \mathrm{G}$ conditions (Figure 2-2B).

As shown in Figure 2-2A ( $\mathrm{n}=6,0 \mathrm{~h} \mathrm{BV}+\mathrm{H}+$ low $\mathrm{G}, 1.52 \pm 0.12 ; 6$ h BV+H+low G, 1.58 $\pm 0.14 ; 15$ h BV+H+low G, 0.78 $\pm 0.13 ; 24$ h BV
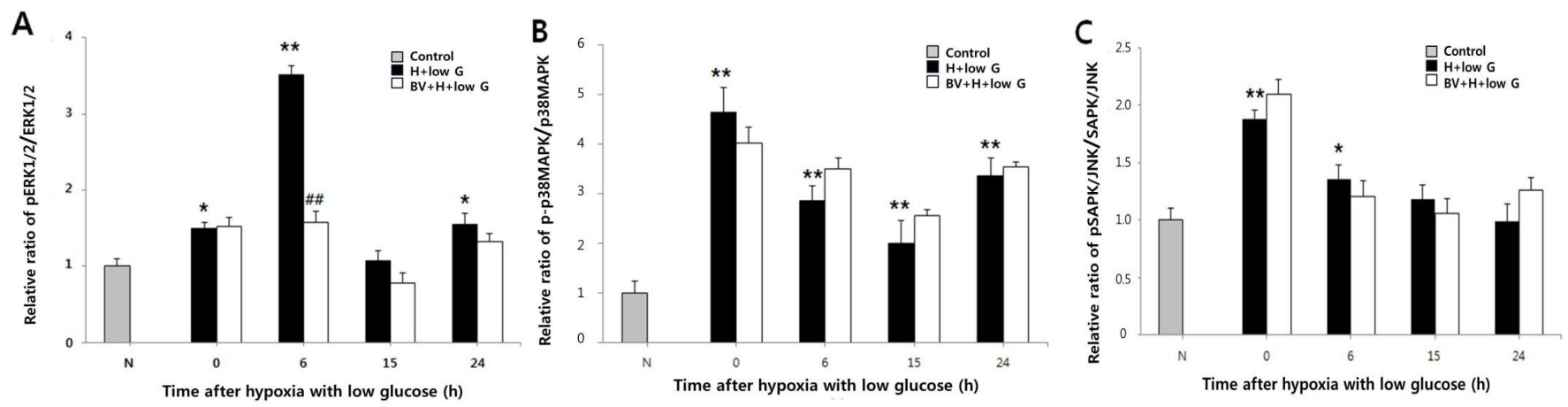

Figure 2-2. Relative phospho-/nonphospho-ratio in MAPK signal pathways in neuronal cells. (A) ERK1/2 phosphorylation was significantly decreased in the $\mathrm{BV}+\mathrm{H}+$ low $\mathrm{G}$ group $6 \mathrm{~h}$ following exposure to $\mathrm{H}+$ low $\mathrm{G}$ conditions; (B) BV pretreatment did not affect the p38 MAPK phosphorylation at $0,6,15$, or $24 \mathrm{~h}$ following exposure to $\mathrm{H}+$ low $\mathrm{G}$ conditions, compared to the $\mathrm{H}+\mathrm{low} \mathrm{G}$ group; (C) BV pretreatment did not affect the SAPK/JNK phosphorylation at $0,6,15$, or $24 \mathrm{~h}$ following exposure to H+low G conditions compared to the $\mathrm{H}+$ low $\mathrm{G}$ group. $\mathrm{H}+$ low $\mathrm{G}$ and $\mathrm{BV}+\mathrm{H}+$ low $\mathrm{G}$ denote conditions of hypoxia with low glucose alone and BV-pretreated hypoxia with low glucose, respectively. MAPK represents mitogen-activated protein kinase. $\mathrm{N}$ represents normoxia. The elapsed time after exposure to $\mathrm{H}+$ low $\mathrm{G}$ conditions is represented by $0 \mathrm{~h}, 6 \mathrm{~h}, 15 \mathrm{~h}$, and $24 \mathrm{~h}\left({ }^{*} \mathrm{P}<0.05,{ }^{*} \mathrm{P}<0.01\right.$ for the $\mathrm{H}+\mathrm{low} \mathrm{G}$ group compared to the $\mathrm{N}$ group; \#\# $\mathrm{P}<$ 0.01 for the $\mathrm{BV}+\mathrm{H}+$ low $\mathrm{G}$ group compared to the $\mathrm{H}+$ low $\mathrm{G}$ group). ERK1/2, extracellular-signal-regulated kinases 1/2; SAPK/JNK, stressactivated protein kinases (SAPK)/Jun amino-terminal kinases (JNK). 
+ H+low G, 1.32 \pm 0.11 ), phosphorylation of ERK1/2 was significantly reduced $6 \mathrm{~h}$ following exposure to $\mathrm{H}+$ low $\mathrm{G}$ condition in the $\mathrm{BV}+\mathrm{H}+$ low $\mathrm{G}$ group compared to the $\mathrm{H}+$ low $\mathrm{G}$ group. BV did not affect p38 MAPK (n=6, Figure 2-2B; 0 h BV+H+low G, 4.01 $\pm 0.33 ; 6$ h BV+H+low G, 3.50 $\pm 0.22 ; 15$ h BV+H+low G, $2.55 \pm$

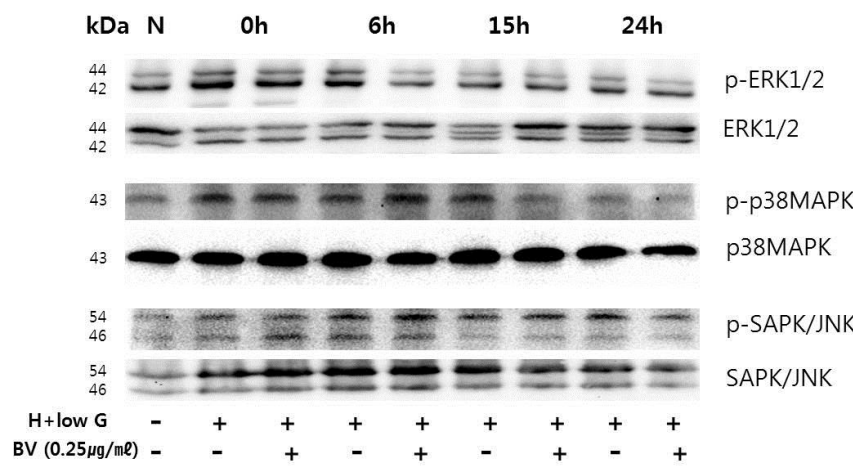

Figure 3-1. Western blot analysis of MAPK signal pathways following exposure to $\mathrm{H}+$ low $\mathrm{G}$ conditions in both the $\mathrm{H}+$ low $\mathrm{G}$ group and the $\mathrm{BV}+\mathrm{H}+$ low $\mathrm{G}$ group in astrocytes. Astrocytes were pretreated with $2.5 \mu \mathrm{g} / \mathrm{mL}$ of bee venom (BV) for $1 \mathrm{~h}$ and then exposed to H+low $\mathrm{G}$ conditions for $18 \mathrm{~h}$. Nuclear extracts were subjected to a western blot using antibodies against ERK1/2, p38 MAPK, SAPK/JNK, p-ERK1/2, p-p38 MAPK, and p-SAPK/JNK. p-ERK1/2, p-p38 MAPK, and p-SAPK/JNK denote antibodies against the phosphorylated form of each protein. $\mathrm{H}+$ low $\mathrm{G}$ and $\mathrm{BV}+\mathrm{H}+$ low $\mathrm{G}$ denote conditions of hypoxia with low glucose alone and BV-pretreated hypoxia with low glucose, respectively. MAPK represents mitogen-activated protein kinase. $\mathrm{N}$ represents normoxia. The elapsed time after exposure to $\mathrm{H}+$ low $\mathrm{G}$ conditions id represented by $0 \mathrm{~h}, 6 \mathrm{~h}, 15 \mathrm{~h}$, and $24 \mathrm{~h}$. ERK1/2, extracellular-signalregulated kinases $1 / 2$; SAPK/JNK, stress-activated protein kinases (SAPK)/Jun amino-terminal kinases (JNK).
0.13; 24 h BV+H+low G, 3.53 \pm 0.11 ) or SAPK/JNK phosphorylation (n=6, Figure 2-2C; 0 h BV+H+low G, 2.10 $\pm 0.12 ; 6$ h BV+ H+low G, 1.20 $\pm 0.14 ; 15$ h BV+H+low G, 1.06 $\pm 0.13 ; 24$ h BV+H+ low $\mathrm{G}, 1.26 \pm 0.11)$.

\section{Effect of BV on Activation of MAPKs Following Exposure to $\mathrm{H}+$ low $\mathrm{G}$ Conditions in a Astrocytes}

The time courses of MAPK family activation was determined in astrocytes the same way as in the neuronal cells (Figure 3-1 and Figure 3-2). Phosphorylation of ERK was increased about 1.4- and 2.4-fold at $0 \mathrm{~h}$ and $6 \mathrm{~h}$, respectively, in the $\mathrm{H}+$ low $\mathrm{G}$ group compared to the $\mathrm{N}$ group $(\mathrm{n}=6$, Figure $3-2 \mathrm{~A} ; \mathrm{N}, 1.00 \pm 0.10$;

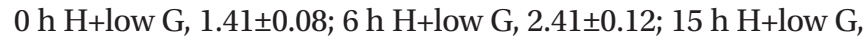
$1.19 \pm 0.13 ; 24$ h H+low G, 0.97 \pm 0.14 ). Six hours following exposure to $\mathrm{H}+$ low $\mathrm{G}$ condition, phosphorylation of ERK1/2 was reduced in the $\mathrm{BV}+\mathrm{H}+$ low $\mathrm{G}$ group (up to $35 \%$ of the $\mathrm{H}+$ low $\mathrm{G}$ group) (n=6, Figure 3-2A; 0 h BV+H+low G, 1.79 $\pm 0.12 ; 6$ h BV+ H+low G, 0.84 $\pm 0.14 ; 15$ h BV+H+low G, 1.01 $\pm 0.13 ; 24$ h BV+ H+low G, 0.89 \pm 0.10 ).

Phosphorylations of p38 MAPK (n=6, Figure 3-2B; N, 1.00 \pm 0.10; 0 h H+low G, 1.38 $\pm 0.08 ; 6$ h H+low G, 1.29 $\pm 0.12 ; 15$ h H+ low G, 1.12 \pm 0.13 ; $24 \mathrm{~h} \mathrm{H}+$ low $\mathrm{G}, 0.89 \pm 0.15)$ and SAPK/JNK (n= 6, Figure 3-2C; N, 1.00 $\pm 0.10 ; 0$ h H+low G, 1.22 $\pm 0.14 ; 6$ h H+low G, 0.97 $\pm 0.12 ; 15$ h H+low G, 0.92 $\pm 0.13 ; 24$ h H+low G, 0.95 \pm 0.15 ) was increased about 1.4- and 1.25-fold, respectively, in the $\mathrm{H}+$ low $\mathrm{G}$ group compared to the $\mathrm{N}$ group, following hypoxic insult. The p38 MAPK activation was sustained $6 \mathrm{~h}$ following exposure to $\mathrm{H}+$ low $\mathrm{G}$ condition (Figure 3-2B). As in the neuronal cells,
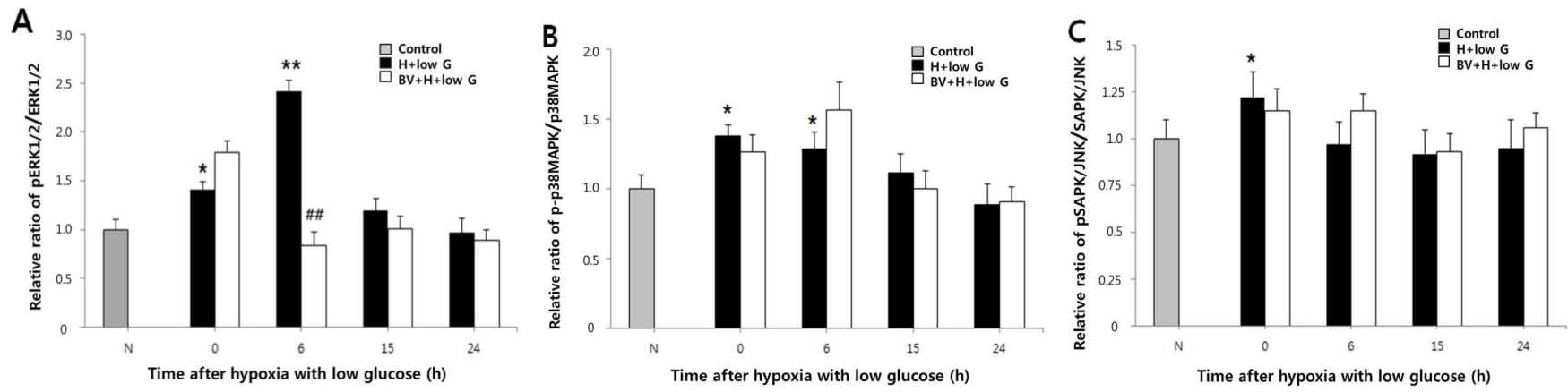

Figure 3-2. Relative phospho-/nonphospho-ratio in MAPK signal pathways in astrocytes. (A) ERK1/2 phosphorylation was significantly decreased in the BV+H+low G group $6 \mathrm{~h}$ following exposure to $\mathrm{H}+$ low $\mathrm{G}$ conditions; (B) BV pretreatment did not affect the p38 MAPK phosphorylation at $0,6,15$, or $24 \mathrm{~h}$ following exposure to $\mathrm{H}+$ low $\mathrm{G}$ conditions, compared to the $\mathrm{H}+\mathrm{low} \mathrm{G}$ group; (C) BV pretreatment did not affect the SAPK/JNK phosphorylation at $0,6,15$, or $24 \mathrm{~h}$ following exposure to H+low G conditions, compared to the H+low $\mathrm{G}$ group. $\mathrm{H}+$ low $\mathrm{G}$ and $\mathrm{BV}+\mathrm{H}+$ low $\mathrm{G}$ denote conditions of hypoxia with low glucose alone and BV-pretreated hypoxia with low glucose, respectively. MAPK represents mitogen-activated protein kinase. $\mathrm{N}$ represents normoxia. The elapsed time after exposure to $\mathrm{H}+$ low $\mathrm{G}$ conditions is represented by $0 \mathrm{~h}, 6 \mathrm{~h}, 15 \mathrm{~h}$, and $24 \mathrm{~h}\left({ }^{*} P<0.05\right.$, ${ }^{* *} P<0.01$ for the $\mathrm{H}+$ low G group compared to the $\mathrm{N}$ group; \#\#P<0.01 for the $\mathrm{BV}+\mathrm{H}+$ low $\mathrm{G}$ group compared to the H+low G group). MAPK, mitogen-activated protein kinase; ERK1/2, extracellular-signal-regulated kinases 1/2; SAPK/JNK, stress-activated protein kinases (SAPK)/Jun amino-terminal kinases (JNK). 
BV did not affect p38 MAPK (n=6, Figure 3-2B; 0 h BV+H+low G, 1.27 $\pm 0.12 ; 6$ h BV+H+low G, 1.57 $\pm 0.20 ; 15$ h BV+H+low G, $1.00 \pm 0.13 ; 24$ h BV+H+low $\mathrm{G}, 0.91 \pm 0.11$ ) or SAPK/JNK activation (n=6, Figure 3-2C; 0 h BV+H+low G, 1.15 $\pm 0.12 ; 6$ h BV+H+ low G, 1.15 \pm 0.09 ; 15 h BV+H+low G, 0.93 $\pm 0.10 ; 24$ h BV+H+low $\mathrm{G}, 1.06 \pm 0.08$ ) during the experiment.

\section{Effect of BV on Neuronal Cell Viability}

Viability of cultured neuronal cells was measured by MTT assay (Figure 4). The H+low G group (n=6, N, 100 \pm 3 ; 0 h H+low

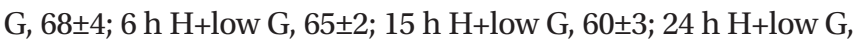
$66 \pm 1)$ showed a significant $(P<0.05)$ decrease in neuronal cell viability compared to that of the $\mathrm{N}$ group $15 \mathrm{~h}$ following exposure to $\mathrm{H}+$ low $\mathrm{G}$ condition. BV pretreament improved cell

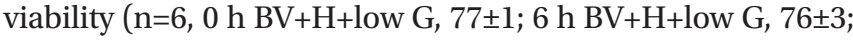
15 h BV+H+low G, 93 \pm 3 ; 24 h BV+H+low G, 75 \pm 2) significantly $(P<0.05)$ in neuronal cells $15 \mathrm{~h}$ following exposure to $\mathrm{H}+$ low $\mathrm{G}$ condition. However, BV pretreatment did not influence cell viability in neuronal cells at timepoints of 0,6 , or $24 \mathrm{~h}$ following exposure $\mathrm{H}+$ low $\mathrm{G}$ condition.

\section{Effect of BV on Astrocyte Viability}

Astrocyte viability of the H+low G group ( $\mathrm{n}=6, \mathrm{~N}, 100 \pm 1 ; 0 \mathrm{~h}$ H+low G, 83 \pm 3 ; 6 h H+low G, 76 \pm 5 ; 15 h H+low G, 78 \pm 3 ; 24 h H+ low $\mathrm{G}, 85 \pm 2)$ was significantly $(P<0.05)$ decreased compared to that of the N group (Figure 5). Fifteen hours after insult, astro-

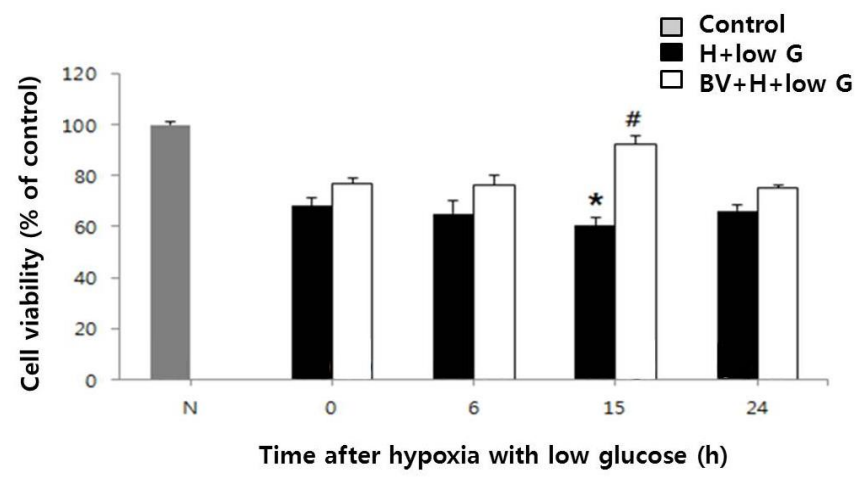

Figure 4. A 3-(4,5-dimethylthiazol-2-yl)-2,5-diphenyl-tetrazolium bromide (MTT) assay was done to measure cell viability in neuronal cells. Fifteen hours following exposure to $\mathrm{H}+$ low $\mathrm{G}$ conditions, the cell viability was improved in the $\mathrm{BV}+\mathrm{H}+$ low $\mathrm{G}$ group. $\mathrm{H}+$ low $\mathrm{G}$, and $\mathrm{BV}+\mathrm{H}+$ low $\mathrm{G}$ denote conditions of hypoxia with low glucose alone and BV-pretreated hypoxia with low glucose, respectively. $\mathrm{N}$ represents normoxia and $0 \mathrm{~h}, 6 \mathrm{~h}, 15 \mathrm{~h}$, and $24 \mathrm{~h}$ represent the elapsed time after exposure to $\mathrm{H}+$ low $\mathrm{G}$ conditions $\left({ }^{*} P<0.05\right.$ for the $\mathrm{H}+$ low $\mathrm{G}$ group compared to the $\mathrm{N}$ group; $\# P<0.05$ for the $\mathrm{BV}+\mathrm{H}+$ low $\mathrm{G}$ group compared to the $\mathrm{H}+$ low $\mathrm{G}$ group). cyte viability was significantly improve $(P<0.05)$ by BV pretreatment (n=6, 0 h BV+H+low G, 91 $\pm 2 ; 6$ h BV+H+low G, 81 $\pm 4 ; 15$ h $\mathrm{BV}+\mathrm{H}+$ low $\mathrm{G}, 91 \pm 3 ; 24 \mathrm{~h} \mathrm{BV+H+low} \mathrm{G,} \mathrm{88 \pm 1).} \mathrm{However,} \mathrm{0,} \mathrm{6,} \mathrm{and}$ $24 \mathrm{~h}$ following exposure to $\mathrm{H}+$ low $\mathrm{G}$ condition, $\mathrm{BV}$ pretreatment had no effect on cell viability in the $\mathrm{H}+$ low $\mathrm{G}$ group.

\section{DISCUSSION}

The present study demonstrated that BV pretreatment improves cell viability in neuronal cells and astrocytes exposed to $\mathrm{H}+$ low $\mathrm{G}$ conditions. BV inhibited the phosphorylation of ERK1/2 in both neuronal cells and astrocytes following exposure to H+low G conditions. ERK1/2, p38 MAPK, and SAPK/ JNK were significantly upregulated in $\mathrm{H}+$ low $\mathrm{G}$ conditions in both neuronal cells and astrocytes, which is consistent with previously reported findings in hypoxic injuries ${ }^{14,27)}$. However, there were some differences in time taken to achieve maximal activation after hypoxic insult among MAPKs.

In neuronal cells, phosphorylation of ERK was increased following exposure to $\mathrm{H}+$ low $\mathrm{G}$ conditions, reached peak level $6 \mathrm{~h}$ following exposure, and showed the lowest levels $15 \mathrm{~h}$ following exposure. In astrocytes, phosphorylation of ERK was increased following exposure to $\mathrm{H}+$ low $\mathrm{G}$ conditions, reached peak level $6 \mathrm{~h}$ following exposure, and then gradually decreas-

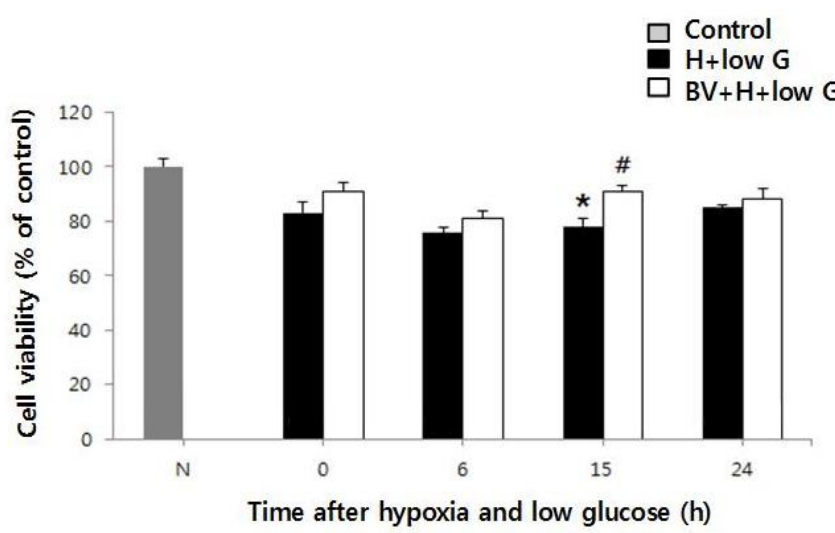

Figure 5. A 3-(4,5-dimethylthiazol-2-yl)-2,5-diphenyl-tetrazolium bromide (MTT) assay was done to measure cell viability in astrocytes. Fifteen hours following exposure to $\mathrm{H}+$ low $\mathrm{G}$ conditions, the cell viability was improved in the $\mathrm{BV}+\mathrm{H}+$ low $\mathrm{G}$ group. $\mathrm{H}+\mathrm{low} \mathrm{G}$, and $\mathrm{BV}+\mathrm{H}+$ low $\mathrm{G}$ denote conditions of hypoxia with low glucose alone and BV-pretreated hypoxia with low glucose, respectively. $\mathrm{N}$ represents normoxia and $0 \mathrm{~h}, 6 \mathrm{~h}, 15 \mathrm{~h}$, and $24 \mathrm{~h}$ represent the elapsed time after exposure to $\mathrm{H}+$ low $\mathrm{G}$ conditions $\left({ }^{*} P<0.05\right.$ for the $\mathrm{H}+$ low $\mathrm{G}$ group compared to the $\mathrm{N}$ group; $\# P<0.05$ for the $\mathrm{BV}+\mathrm{H}+$ low $\mathrm{G}$ group compared to the $\mathrm{H}+$ low $\mathrm{G}$ group). 
ed until the $24 \mathrm{~h}$ timepoint. It has been reported that maximal ERK activation occurs several hours after hypoxic insult ${ }^{9,28,29)}$. The results obtained from this study are consistent with other recent reports.

The phosphorylation level of p38 MAPK and SAPK/JNK reached a maximum just after hypoxic insult in neuronal cells and astrocytes. These data are consistent with previously reported findings ${ }^{12,21)}$. These findings suggest that activation of p38 MAPK and SAPK/JNK after hypoxic insult may be an early and transient event.

Several studies have demonstrated that MAPKs are activated after hypoxic insult ${ }^{12,25,26,30)}$. There is increasing evidence that inhibition of MAPK pathways can alter the outcome of $\mathrm{HI}$ brain injury by regulating cell death or survival in animal models ${ }^{11,31)}$. However, previous reports show conflicting evidence regarding the role of the MAPK pathways (particularly ERKs) in cell survival or neuroprotection under conditions hypoxia or neuronal injury $^{32)}$.

ERKs are important regulators of neuronal function ${ }^{33)}$. Activation of ERK has been reported to contribute to neuronal death in some models of neurotoxicity ${ }^{3,15)}$. The mechanisms that mediate these deleterious effects of ERK activation have not been fully elucidated. They may include the release of excitotoxic glutamate by ERK activation $^{34)}$. It has been reported that ERK activation is prominently involved in neurodegeneration, such as ischemia in animal models ${ }^{35)}$. Prolonged ERK stimulation ultimately promotes neuron degeneration through plasma membrane damage via caspase-dependent or -independent mechanisms ${ }^{35)}$. Prolonged activation of ERK is also associated with neuronal apoptotic cell death in response to ROS production in the hippocampal cell line HT22 ${ }^{36)}$. Furthermore, it has been demonstrated that inhibition of ERK activation protects against cell damage after HI exposure ${ }^{9,20,27,29)}$.

However, ERK signaling has also been reported to be involved in neurogenesis. It can induce tolerance to $\mathrm{HI}$ injury in brains of newborn rats ${ }^{15)}$. In addition to an inflammatory response, the brain may respond to hypoxia by neurogenesis and release of growth factors. For example, nerve growth factor can induce the ERK1/2 signaling pathway ${ }^{37)}$. Several reports have suggested that the ERK1/2 signaling pathway can increase cell survival through the activation of cAMP response element-binding protein $(\mathrm{CREB})^{15,35,36)}$. ERK1/2 activation has been observed in the ischemic necrotic core shortly after $\mathrm{HI}$ neuronal injury in neonatal rats ${ }^{33)}$. It has been reported that differential ERK1/2 acti- vation at later time points after HI exposure is also found in different cell types (neuronal cells, microglial cells, astrocytes and oligodendrocytes) in the penumbra area, suggesting a dual role of ERK1/2 in cell survival and/or cell death ${ }^{15)}$. These reports suggest that the neuroprotective role of ERK1/2 may depend on the duration and timing of its activation ${ }^{33)}$. A recent study has shown that the caspase-dependent component of cell death after neonatal HI does not peak until 12-24 h after injury $^{38)}$. This finding suggests that there is a possible therapeutic window in which effects of ERK activation on both transcriptiondependent and -independent mechanisms could influence cell survival.

Recently, BV has been increasingly implicated in modulating intracellular signaling pathways including MAPKs ${ }^{2,6,13,21,39)}$. In this study, BV pretreatment inhibited the H+low G-induced ERK phosphorylation. However, it did not affect the phosphorylation of JNK or p38 MAPKs in astrocytes or neuronal cells. This is in some contradiction to a previous report, in which they showed that BV inhibited the early phosphorylation of ERK, p38 MAPK, and JNK following glutamate-induced toxicity ${ }^{3)}$. According to their report, JNK and p38 MAPK were associated with the neuroprotective function of BV.

This study showed that BV inhibited early JNK and p38 phosphorylation at $0 \mathrm{~h}$ but this did not show statistical significance. Further studies are needed to clarify this mechanisms of BV. In an earlier report, the inhibition of the p38 MAPK has no influence on cell proliferation determined $6 \mathrm{~d}$ after ischemia. Early blockage of p38 phosphorylation in activated microglial cells could influence neurogenesis ${ }^{11)}$. Therefore, these findings led to the suggestion that the functional relevance of MAPK activation may depend upon the cell type, the nature of the stimulus, and the environmental conditions ${ }^{40)}$.

The present study showed that the neuronal cell and astrocyte injuries were reduced in the $\mathrm{BV}+\mathrm{H}+$ low $\mathrm{G}$ group. When considering the time sequence of the inhibitory effect of BV on MAPK phosphorylation and cell viability, the increase in cell viability in the $\mathrm{BV}+\mathrm{H}+$ low $\mathrm{G}$ group compared to that in the $\mathrm{H}+$ low $\mathrm{G}$ group may be due to inhibition of ERK pathways. The results suggest that inhibition of ERK phosphorylation with BV pretreatment results in a neuroprotective effect rather than neurotoxicity.

A limitation of this study is that we treated cells with different concentrations of BV. At an optimal concentration of BV in astrocytes, BV decreased cell viability in neuronal cells. Thus, 
further studies are needed to define optimal and harmless concentrations of $\mathrm{BV}$ in both neuronal cells and astrocytes for in vivo application.

In conclusion, the present study demonstrated that BV inhibits the activation of ERK1/2 in both neuronal cells and astrocytes following exposure to $\mathrm{H}+$ low $\mathrm{G}$ conditions, as well as improving cell viability. BV specifically inhibited the phosphorylation of ERK1/2 without changing the total protein levels. However, BV had no effects on p38 MAPK or SAPK/JNK phosphorylation. These results suggest that BV pretreatment may have a neuroprotective effect by regulating ERK activation following exposure to $\mathrm{H}+$ low $\mathrm{G}$ conditions.

\section{ACKNOWLEDGEMENT}

This work was supported by the grant of Research Institute of Medical Science, Catholic University of Daegu (2015)

\section{REFERENCES}

1) Esch RE. Allergen source materials and quality control of allergenic extracts. Methods 1997;13:2-13.

2) Choi KE, Hwang CJ, Gu SM, Park MH, Kim JH, Park JH, et al. Cancer cell growth inhibitory effect of bee venom via increase of death receptor 3 expression and inactivation of NF-kappa B in NSCLC cells. Toxins (Basel) 2014;6:2210-28.

3) Lee SM, Yang EJ, Choi SM, Kim SH, Baek MG, Jiang JH. Effects of bee venom on glutamate-induced toxicity in neuronal and glial cells. Evid Based Complement Alternat Med 2012; 2012:368196

4) Kwon YB, Lee JD, Lee HJ, Han HJ, Mar WC, Kang SK, et al. Bee venom injection into an acupuncture point reduces arthritis associated edema and nociceptive responses. Pain 2001;90:271-80.

5) Wu J, Jiang H, Bi Q, Luo Q, Li J, Zhang Y, et al. Apaminmediated actively targeted drug delivery for treatment of spinal cord injury: More than just a concept. Mol Pharm 2014; 11:3210-22.

6) Liu CC, Yang H, Zhang LL, Zhang Q, Chen B, Wang Y. Biotoxins for cancer therapy. Asian Pac J Cancer Prev 2014;15:47538.

7) Cho HJ, Jeong YJ, Park KK, Park YY, Chung IK, Lee KG, et al. Bee venom suppresses PMA-mediated MMP-9 gene activation via JNK/p38 and NF-kappaB-dependent mechanisms.
J Ethnopharmacol 2010;127:662-8.

8) Li J, Qu Y, Chen D, Zhang L, Zhao F, Luo L, et al. The neuroprotective role and mechanisms of TERT in neurons with oxygenglucose deprivation. Neuroscience 2013;252:346-58.

9) Li L, Yin X, Ma N, Lin F, Kong X, Chi J, et al. Desferrioxamine regulates HIF-1 alpha expression in neonatal rat brain after hypoxia-ischemia. Am J Transl Res 2014;6:377-83.

10) Chechneva O, Dinkel K, Cavaliere F, Martinez-Sanchez $M$, Reymann KG. Anti-inflammatory treatment in oxygenglucose-deprived hippocampal slice cultures is neuroprotective and associated with reduced cell proliferation and intact neurogenesis. Neurobiol Dis 2006;23:247-59.

11) Strassburger $M$, Braun H, Reymann KG. Anti-inflammatory treatment with the p38 mitogen-activated protein kinase inhibitor SB239063 is neuroprotective, decreases the number of activated microglia and facilitates neurogenesis in oxygenglucose-deprived hippocampal slice cultures. Eur J Pharmacol 2008;592:55-61.

12) Lu Q, Rau TF, Harris V, Johnson M, Poulsen DJ, Black SM. Increased p38 mitogen-activated protein kinase signaling is involved in the oxidative stress associated with oxygen and glucose deprivation in neonatal hippocampal slice cultures. Eur J Neurosci 2011;34:1093-101.

13) Zhang N, Gao G, Bu X, Han S, Fang L, Li J. Neuron-specific phosphorylation of c-jun $\mathrm{N}$-terminal kinase increased in the brain of hypoxic preconditioned mice. Neurosci Lett 2007; 423:219-24.

14) Kim BC, Kim MK, Cho KH, Kim YS, Lee KY. Activation of mitogen-activated protein kinases in hypoxia-induced apoptosis of PC12 cell. J Korean Neurol Assoc 2001;19:384-92.

15) Jones NM, Bergeron M. Hypoxia-induced ischemic tolerance in neonatal rat brain involves enhanced ERK1/2 signaling. J Neurochem 2004;89:157-67.

16) Weston CR, Lambright DG, Davis RJ. Signal transduction. MAP kinase signaling specificity. Science 2002;296:2345-7.

17) Chen L, Liu L, Yin J, Luo Y, Huang S. Hydrogen peroxideinduced neuronal apoptosis is associated with inhibition of protein phosphatase $2 \mathrm{~A}$ and 5 , leading to activation of MAPK pathway. Int J Biochem Cell Biol 2009;41:1284-95.

18) Cui XY, Dai Y, Wang SL, Yamanaka $H$, Kobayashi $K$, Obata $K$, et al. Differential activation of p38 and extracellular signalregulated kinase in spinal cord in a model of bee venominduced inflammation and hyperalgesia. Mol Pain 2008;4:17.

19) Moon DO, Park SY, Heo MS, Kim KC, Park C, Ko WS, et al. Key regulators in bee venom-induced apoptosis are bcl-2 and caspase-3 in human leukemic U937 cells through downregulation of ERK and akt. Int Immunopharmacol 2006;6:1796807.

20) Tang Z, Sun X, Huo G, Xie Y, Shi Q, Chen S, et al. Protective 
effects of erythropoietin on astrocytic swelling after oxygenglucose deprivation and reoxygenation: mediation through AQP4 expression and MAPK pathway. Neuropharmacology 2013;67:8-15.

21) Nito C, Kamada H, Endo H, Narasimhan P, Lee YS, Chan PH. Involvement of mitogen-activated protein kinase pathways in expression of the water channel protein aquaporin-4 after ischemia in rat cortical astrocytes. J Neurotrauma 2012;29: 2404-12.

22) Tu YF, Tsai YS, Wang LW, Wu HC, Huang CC, Ho CJ. Overweight worsens apoptosis, neuroinflammation and bloodbrain barrier damage after hypoxic ischemia in neonatal brain through JNK hyperactivation. J Neuroinflammation 2011;8:40.

23) Lee WR, Kim KH, An HJ, Kim JY, Chang YC, Chung H, et al. The protective effects of melittin on propionibacterium acnesinduced inflammatory responses in vitro and in vivo. J Invest Dermatol 2014;134:1922-30.

24) Jeong JK, Moon MH, Bae BC, Lee YJ, Seol JW, Park SY. Bee venom phospholipase A2 prevents prion peptide induced-cell death in neuronal cells. Int J Mol Med 2011;28:867-73.

25) Brewer GJ. Isolation and culture of adult rat hippocampal neurons. J Neurosci Methods 1997;71:143-55.

26) Borlongan CV, Yamamoto M, Takei N, Kumazaki M, Ungsuparkorn $\mathrm{C}$, Hida $\mathrm{H}$, et al. Glial cell survival is enhanced during melatonin-induced neuroprotection against cerebral ischemia. FASEB J 2000;14:1307-17.

27) Lan A, Liao X, Mo L, Yang C, Yang Z, Wang X, et al. Hydrogen sulfide protects against chemical hypoxia-induced injury by inhibiting ROS-activated ERK1/2 and p38MAPK signaling pathways in PC12 cells. PLoS One 2011;6:e25921.

28) Shin JM, Jeong YJ, Park KK, Choe JY, Han SM, Lee KG, et al. Bee venom inhibits angiogenesis by decreasing HIF- $1 \alpha$ expression in HCT116 cells. J Life Science 2012;22:41-8.

29) Shin JM, Jeong YJ, Cho HJ, Park KK, Chung IK, Lee IK, et al. Melittin suppresses HIF-1alpha/VEGF expression through inhibition of ERK and mTOR/p70S6K pathway in human cervical carcinoma cells. PLoS One 2013;8:e69380.

30) Li J, Zhang S, Lu M, Chen Z, Chen C, Han L, et al. Hydroxysafflor yellow a suppresses inflammatory responses of BV2 microglia after oxygen-glucose deprivation. Neurosci Lett
2013;535:51-6.

31) Ferrer I, Friguls B, Dalfo E, Planas AM. Early modifications in the expression of mitogen-activated protein kinase (MAPK/ ERK), stress-activated kinases SAPK/JNK and p38, and their phosphorylated substrates following focal cerebral ischemia. Acta Neuropathol 2003;105:425-37.

32) Chiu BY, Chang CP, Lin JW, Yu JS, Liu WP, Hsu YC, et al. Beneficial effect of astragalosides on stroke condition using PC12 cells under oxygen glucose deprivation and reperfusion. Cell Mol Neurobiol 2014;34:825-37.

33) Grewal SS, York RD, Stork PJ. Extracellular-signal-regulated kinase signalling in neurons. Curr Opin Neurobiol 1999;9:54453.

34) Murray B, Alessandrini A, Cole AJ, Yee AG, Furshpan EJ. Inhibition of the p44/42 MAP kinase pathway protects hippocampal neurons in a cell-culture model of seizure activity. Proc Natl Acad Sci U S A 1998;95:11975-80.

35) Subramaniam S, Zirrgiebel U, von Bohlen Und Halbach O, Strelau J, Laliberte C, Kaplan DR, et al. ERK activation promotes neuronal degeneration predominantly through plasma membrane damage and independently of caspase-3. J Cell Biol 2004;165:357-69.

36) Cagnol S, Van Obberghen-Schilling E, Chambard JC. Prolonged activation of ERK1,2 induces FADD-independent caspase 8 activation and cell death. Apoptosis 2006;11:337-46.

37) Lin Y, Liu A, Lu N, Li Y, Song Q, Yu H, et al. Inhibitive effects of low oxygen and glucose deprivation on brain-pancreas relative protein expression via hypoxia- inducible factor-1 pathways. Cell Physiol Biochem 2008;22:353-62.

38) Han BH, Holtzman DM. BDNF protects the neonatal brain from hypoxic-ischemic injury in vivo via the ERK pathway. J Neurosci 2000;20:5775-81.

39) Yang X, Zhu H, Ge Y, Liu J, Cai J, Qin Q, et al. Melittin enhances radiosensitivity of hypoxic head and neck squamous cell carcinoma by suppressing HIF-1alpha. Tumour Biol 2014;35: 10443-8.

40) Wang MD, Huang Y, Zhang GP, Mao L, Xia YP, Mei YW, et al. Exendin-4 improved rat cortical neuron survival under oxygen/ glucose deprivation through PKA pathway. Neuroscience 2012; 226:388-96. 